\title{
The status of Pteropus livingstonii in the Comores
}

\author{
P. F. Reason and W. J. Trewhella
}

Pteropus livingstonii is one of the world's most endangered fruit bats, with a small population limited to two of the Comoro Islands (western Indian Ocean). Surveys carried out in 1992 and 1993 suggest that the population numbers around 150 individuals. Loss of habitat through deforestation is the major threat to this species. Old World Fruit Bats: An Action Plan for their Conservation recommends captive-breeding of this species as one of 20 priority projects. The FFPS helped fund both the preparation of the Action Plan and the field projects described in this paper.

Many fruit bat populations have suffered serious declines as a result of habitat loss, overhunting or cyclones (Mickleburgh et al., 1992). This is true for many Pteropus species, which are often dependent on primary (or well-regenerated secondary) forest for their feeding and roosting requirements and, although potentially long-lived, have a low reproductive rate (Pierson and Rainey, 1992). This decline is of particular concern in tropical, oceanic island ecosystems where flying foxes play a vital role as pollinators and seed dispersers and thus in forest regeneration (Cox et al., 1992).

The Comoros black flying fox or Livingstone's flying fox Pteropus livingstonii is endemic to the Comores, a group of four islands in the western Indian Ocean (Figure 1). The Comores are affected by major environmental problems, notably soil erosion, deforestation and intermittent tropical cyclones, compounded by a rapid growth in the human population. The situation is most acute on the island of Anjouan, where the majority of $P$. livingstonii are found.

Following recent surveys (Cheke and Dahl, 1981; University of East Anglia, 1988), it became apparent that $P$. livingstonii was in danger of imminent extinction. In response to recommendations in the IUCN Action Plan for Old World Fruit Bats (Mickleburgh et al., 1992), an expedition by Action Comores personnel from the University of Bristol visited the Comores in 1992 (for 7 months) and 1993 (for 6 weeks). The expedition worked in collaboration with the Jersey Wildlife Preservation Trust and with the approval of the Comorien Government. Capture attempts to provide individuals for a captive-breeding programme at Jersey Zoo are described elsewhere (Action Comores, 1992; Young et al., in press), and the project is fully described in the Action Comores reports (Action Comores, 1992, 1993). This paper describes the status of $P$. livingstonii in the Comores, the threats to this species, and conservation recommendations.

\section{The status of $P$. livingstonii prior to 1992}

Pteropus livingstonii was first described following a visit by Livingstone's Zambezi expedition to Anjouan in 1863. It was first recorded on Moheli by Cheke and Dahl (1981), but has not been found on Grande Comore or Mayotte. The only reference to its past status comes from M. Humblot (cited in MilneEdwards and Oustalet, 1888); P. livingstonii apparently 'existed in abundance in the great forests which cover the summit of Anjouan's peak but is never seen in the lowland areas of the coast'. All subsequent sightings on Anjouan and Moheli (reviewed in Action Comores, 1992) suggest that $P$. livingstonii is 

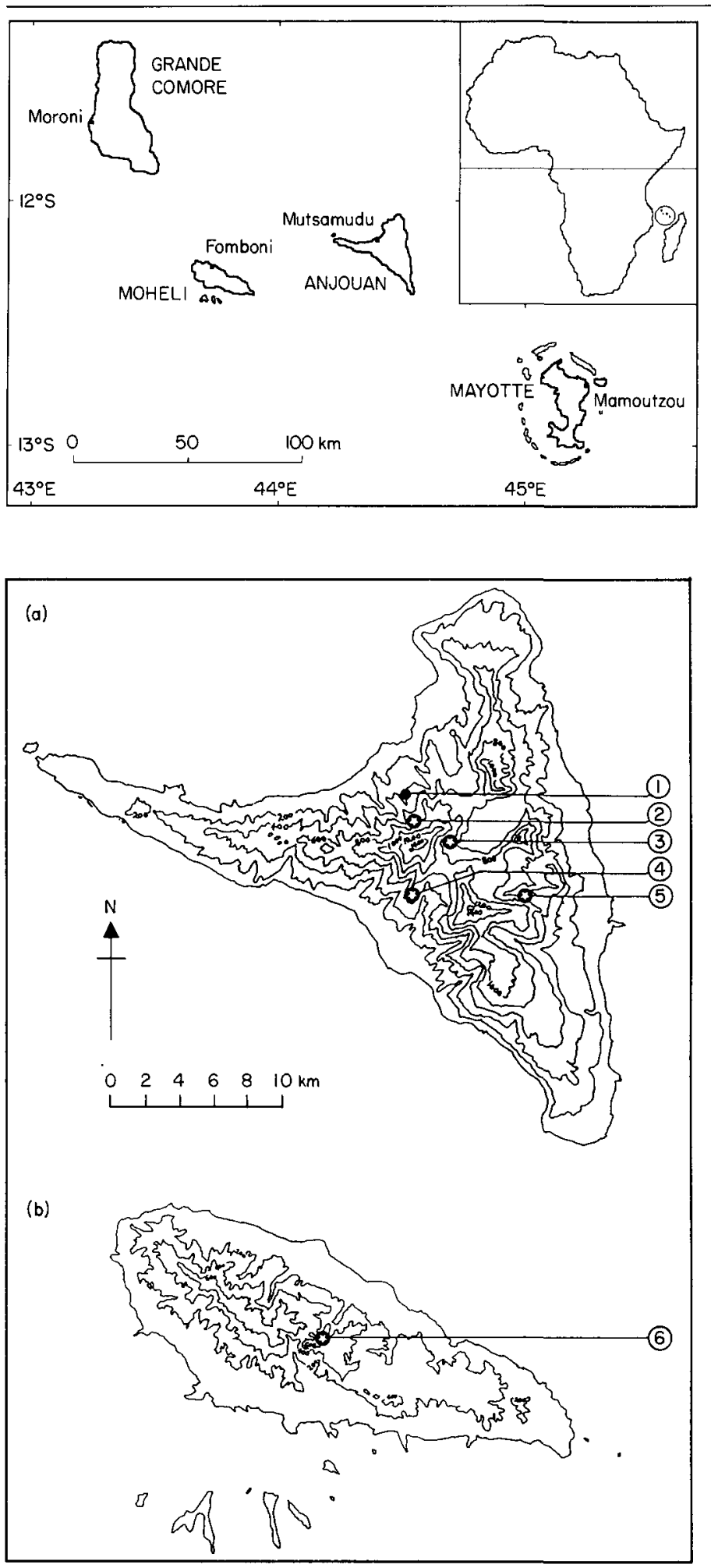

Figure 1. The Comores.

Figure 2. The positions of the Pteropus livingstonii roosts and feeding sites, used in the population estimates, on (a) Anjouan and (b) Moheli. 1, 'Bistro 21'; 2, Hombo; 3, Dindi; 4, Lingoni; 5, Trondroni; 6 , 'chez Pierre'. 
restricted to the montane forest regions.

For both Anjouan and Moheli, Cheke and Dahl's (1981) population estimate was 'no more than a few hundreds, may be less', and they found that $P$. livingstonii was extremely rare. In 1988 between 20 and 30 individuals were sighted on Anjouan, and none on Moheli (University of East Anglia, 1988), with a maximum population estimate of 200. Further population estimates on Anjouan include: 30-40 individuals seen in 1989 (Thorpe, 1989); 60-120 bats estimated in 1990 at one roost (Carroll and Thorpe, 1991); and 80-150 bats estimated at the same roost, with another 20 estimated at a second roost, in 1991 (Hartley and Leaper, 1991).

\section{Field surveys, 1992 and 1993}

Survey work was carried out on Moheli and Anjouan to locate $P$. livingstonii roosts, to estimate the population size and to find suitable sites at which to catch bats to provide individuals for a captive-breeding programme. Direct counts, dispersal counts (as bats left the roost to forage) and disturbance counts were used (Racey, 1979). The number of bats seen often varied during the course of a visit, so for each visit the maximum number observed was recorded.

On Anjouan the positions of two roosts, near the villages of Dindi and Lingoni, were known prior to 1992 . These roosts were visited in 1992 to verify that they were still in use and to obtain population estimates. A third roost above the village of Hombo was discovered after an aid worker saw $P$. livingstonii flying in this region. These three roosts were revisited in 1993. In both years, several other sites ('Enteritis', 'Plaideau's' and Trondroni) were also visited, following reports of $P$. livingstonii sightings.

On Moheli, a roost site that had been found the previous October by an aid worker, the 'chez Pierre' roost, was visited in 1992.

On Anjouan, counts were also made at a feeding site near the Hombo roost, 'Bistro 21', in both years. This was one of the sites where catching took place.

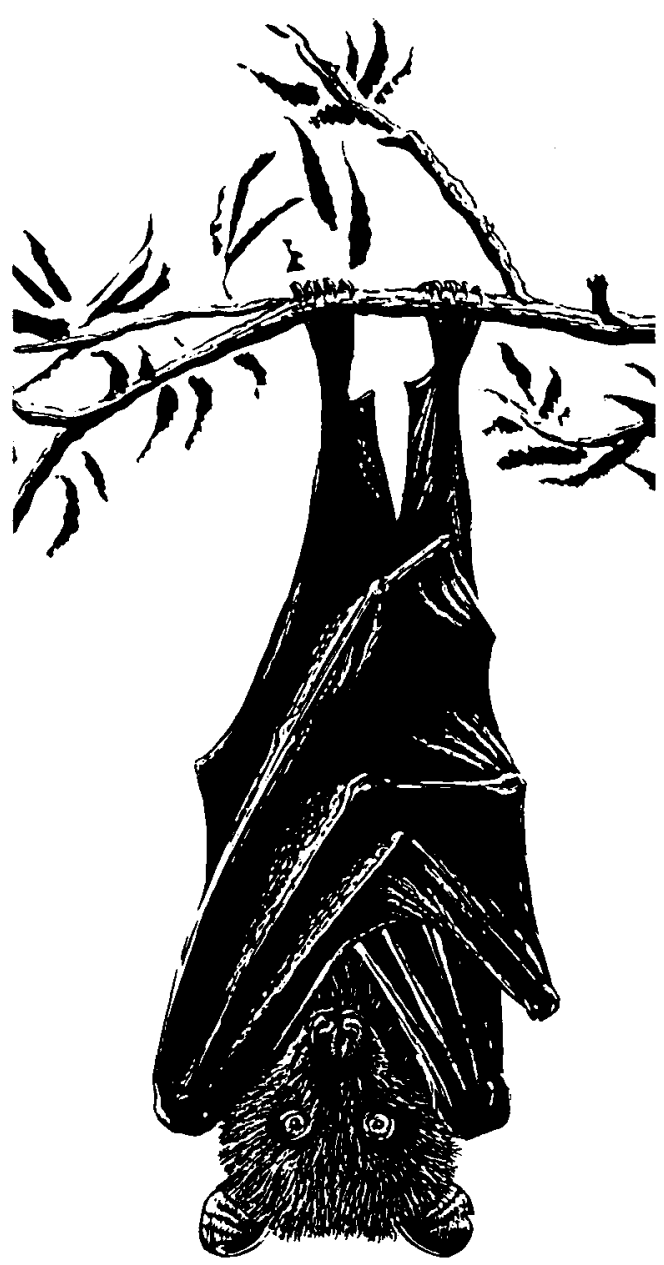

Pteropus livingstonii.

\section{Numbers of bats}

Four major roost sites - Hombo, Lingoni, Dindi, and 'chez Pierre' - were identified (Figure 2). Table 1 shows the number of visits made to, and number of bats seen, at all the roosts.

In 1992 numbers at the Hombo roost varied considerably, reaching a peak of 60 in June, and dropping to a core of around 15 from July onwards. In 1993 the maximum number seen was seven in June. At the Lingoni roost $54 P$. livingstonii were seen in July 1992, and 56 in July 1993. At the Dindi roost 18 bats were 


\begin{tabular}{|c|c|c|c|c|c|}
\hline \multirow[b]{2}{*}{ Site } & \multirow[b]{2}{*}{ Date } & \multicolumn{2}{|l|}{$\underline{1992}$} & \multicolumn{2}{|l|}{1993} \\
\hline & & $\begin{array}{l}\text { No. of } \\
\text { visits }\end{array}$ & $\begin{array}{l}\text { No. of } \\
\text { adults }\end{array}$ & $\begin{array}{l}\text { No. of } \\
\text { visits }\end{array}$ & $\begin{array}{l}\text { No. of } \\
\text { adults }\end{array}$ \\
\hline \multicolumn{6}{|l|}{$\overline{\text { Anjouan }}$} \\
\hline \multirow[t]{6}{*}{ Hombo } & April & 4 & $31-52$ & & \\
\hline & May & 2 & $33-42$ & & \\
\hline & June & 3 & $36-60$ & 2 & $2-7^{*}$ \\
\hline & July & 1 & 18 & & \\
\hline & August & 3 & $4-14$ & & \\
\hline & September & 4 & $13-17$ & & \\
\hline 'Bistro 21' & June-July & - & 50 & 11 & $13-42$ \\
\hline \multirow[t]{3}{*}{ Lingoni } & June & 1 & 23 & 1 & 50 \\
\hline & July & 1 & 54 & 2 & $51-56$ \\
\hline & September & 2 & $16-45$ & & \\
\hline \multirow{6}{*}{ Dindi } & April & 1 & 10 & & \\
\hline & August & 1 & 18 & & \\
\hline & June & & & 1 & 18 \\
\hline & July & & & 1 & 4 \\
\hline & September & 1 & 7 & & \\
\hline & October & 1 & 17 & & \\
\hline \multirow[t]{3}{*}{ 'Enteritis' } & May & 1 & 0 & & \\
\hline & June & 2 & $0-1 \dagger$ & 1 & 0 \\
\hline & September & 1 & 0 & & \\
\hline Trondroni & June & & & 1 & 4 \\
\hline \multirow{3}{*}{ 'Plaideau's' } & June & & & 1 & $4^{*}$ \\
\hline & July & 2 & 0 & & \\
\hline & September & 1 & 0 & & \\
\hline \multicolumn{6}{|l|}{ Moheli } \\
\hline 'chez Pierre' & July & 2 & $12-20$ & & \\
\hline
\end{tabular}

Table 1. The numbers of Pteropus livingstonii seen at each roost or feeding site during 1992 and 1993 (figures in italics are used for population estimates)

* For the 1993 population estimate, the bats at the Hombo and 'Plaideau's' roost were assumed to be some of those visiting the feeding site.

† For the 1992 population estimate, this bat was assumed to be a stray from the Hombo roost.

counted in August 1992 and in June 1993. The 'chez Pierre' roost on Moheli contained 20 bats in July 1992.

From October 1992 to April 1993, the Lingoni roost was visited on a weekly basis by Mohamed Attoumane, a local guide, who made detailed counts. Reported numbers rose from 49 in October, to a maximum of 235 in February, and declined to 124 in April, suggesting a marked wet season increase in the number of bats at this roost. These numbers have not been independently verified and, until further wet season counts are organized, should be treated with extreme caution.

At the 'Bistro 21 ' site regular observations were made at a group of 50 kapok Ceiba pentandra trees, which flowered during June and
July in both years. As the trees came into flower, increasing numbers of $P$. livingstonii visited the site each night. In 11 counts made in 1993 13-42 bats were seen at this site; in 1992 over 50 bats were observed there. In both years numbers subsequently declined as peak flowering passed. In 1992 observations on the flight paths of bats leaving the nearby Hombo roost indicated they were heading for this feeding site; changes in the numbers of bats at the feeding site paralleled changes at the Hombo roost. As the kapok flowering ended $P$. livingstonii foraged in smaller groups and in more scattered sites. In 1993 it was apparent that the bats at this feeding site were not coming from the Hombo roost because of the low numbers seen there. The flight paths of bats 
visiting the feeding site suggested that they originated from the valley parallel to that in which the Hombo roost was situated. On one occasion in July 1992, 17 bats were seen leaving this valley in the late afternoon, but no roost site was identified.

\section{The current status of $\boldsymbol{P}$. livingstonii}

The minimum population estimate for $P$. livingstonii during 1992, based on direct observations from four roosts, was 152 individuals. Of these, 132 were recorded from Anjouan and 20 from Moheli. For 1993, the population estimate on Anjouan was 120 bats from four roost sites and one feeding site. P. livingstonii is still present on Moheli (S. Frodl, pers. comm.) but a roost count was not made in 1993.

These counts are a minimum population estimate based on bats actually seen, rather than those estimated to be present as previous surveys have used. They do not take into consideration any seasonal variation in roost size, as is suggested by changes in numbers at the Hombo and Lingoni roosts. Dramatic seasonal changes in roost composition have been found in at least six other Pteropus species (Nicoll and Racey, 1981; Pierson and Rainey, 1992). It is also possible that other roost sites may still be found on Anjouan and Moheli.

Based on sightings or population estimates, Carroll and Thorpe (1991) stated that the population on Anjouan has declined over the last decade. However, these population estimates, by different observers using different methods, cannot be readily compared. Minimum counts at the Lingoni roost over the last 4 years are 56 individuals in 1993, 54 individuals in 1992, 35 individuals in 1991 (Hartley and Leaper, 1991) and 60 individuals in 1990 (Carroll and Thorpe, 1991). At the Dindi roost 18 individuals were recorded in 1993 and 1992, a minimum of six in 1991 (Hartley and Leaper, 1991), and 13 in 1990 (K. Hunter, pers. comm., cited in Carroll and Thorpe, 1991). From these observations, the populations at Lingoni and Dindi appear not to have declined over the last 4 years.
Speculation that the Moheli population was recently wiped out (University of East Anglia, 1988), is unfounded given the results of the 1992 survey.

Pteropus livingstonii is dependent on primary montane forest, and there is indisputable evidence (Battistini and Vérin, 1984; Weightman, 1987; CARE-Comores, 1991) that this habitat has declined dramatically during this century and at an increasing rate in the last two decades. It is probable that $P$. livingstonii populations will have declined concurrently, or at least contracted their distribution, and thus become increasingly threatened.

\section{Perceived threats to $P$. livingstonii}

Deforestation is the major threat to $P$. livingstonii. On Anjouan, montane forest declined from 28 per cent of the island's surface area in 1923, to 19 per cent in 1971 and 6 per cent (2500 ha) in 1990 (Battistini and Vérin, 1984; Weightman, 1987; CARE-Comores, 1991). P. livingstonii relies on this habitat for roosting and is more dependent on native forest fruits, flowers and leaves than the congeneric $P$. seychellensis comorensis (Action Comores, 1992). On islands with a low floral diversity, the loss of critical plant species through deforestation can affect the survival of Pteropus bats (Pierson and Rainey, 1992).

In 1992 there was evidence of recent, significant forest clearance within $50 \mathrm{~m}$ of two of the roosts. Until recently, the steep slopes and relative inaccessibility of the roost sites provided some protection for the bats, but this will disappear if the demand for land continues at its current level. How much disturbance $P$. livingstonii will tolerate at its roosts is unknown.

Cyclones have a devastating effect on the vegetation of the Comores (Battistini and Vérin, 1984; CARE-Comores, 1991). For the bats, the threat of cyclones can be either direct, destroying the roosts themselves, or indirect, destroying important food plants. The risk of cyclone damage is not independent of deforestation, as the latter leaves the remaining forest more vulnerable to cyclone damage. It is poss- 
ible that a cyclone in 1950 had a significant impact on the population of $P$. livingstonii because there are few trees greater than 40 years old on Anjouan. Cyclones have affected populations of $P$. rodricensis, $P$. niger, $P$. samoensis, $P$. tonganus and P. mariannus mariannus (Carroll, 1985; Pierson and Rainey, 1992), and P. s. comorensis in the Comores (Cheke and Dahl, 1981).

There was no direct evidence of fruit bats being commonly used for food during the surveys, although young Comoriens were occasionally reported to eat them. However, children with catapults were a threat to Pteropus bats. Two P. s. comorensis were taken from children in 1993 having been struck by stones from catapults; both had broken wings and had to be destroyed. On one occasion in 1992, children were seen using catapults against bats at the 'Bistro 21' site, where at least one $P$. livingstonii was seen with a hole in its wing. It is probable that $P$. s. comorensis, rather than $P$. livingstonii, is more threatened by such direct action because it occurs in greater numbers and roosts nearer to villages.

Carroll and Thorpe (1991) speculated that competition may be occurring between $P$. s. comorensis and $P$. livingstonii, with the latter being excluded from its roosts by the former. There was no evidence that $P$. livingstonii was adversely affected by $P$. s. comorensis; in fact, the reverse appeared to be the case, with $P$. livingstonii winning the majority of aggressive encounters observed (Action Comores, 1992). A greater knowledge of food availability and the resource partitioning by both Pteropus species and the mongoose lemur Lemur mongoz is needed before the nature of any potential competition can be fully appreciated.

\section{Conservation management and the future for $\boldsymbol{P}$. livingstoni $i$}

The true status of $P$. livingstonii and trends in the population size can only be ascertained by regular survey work. Population counts must be comparable and direct counts, rather than 'observers' best estimates', should be obtained. To date, surveys have been carried out only in the dry season and by visiting expeditions. Given the infrastructure available on the islands, in situ monitoring would not be an easy operation to organize or verify. Action Comores has given instructions on roost locations and bat identification techniques to members of Ulanga (the Comorien voluntary environmental group) and Peace Corps with the hope of obtaining further counts.

Further research on the feeding ecology of $P$. livingstonii is needed to reveal whether it is food-limited at any time of the year. Smallscale replanting of native fruit-bearing trees could form a significant conservation measure, given that relatively small patches of flowering and fruiting trees can attract large numbers of bats (Action Comores, 1992). Further information on the social structure of roosts and seasonal movement patterns are also relevant to conservation management.

Legislation for the protection of $P$. livingstonii and its roosts is essential. However, the effectiveness of legal protection will be minimal unless resources are deployed for its enforcement. For example, it has been illegal to kill mongoose lemurs on the Comores since 1974, but few Comoriens are aware of this and this law is not enforced (Tattersall, 1977). The existing forestry code is in urgent need of updating, and legal constraints that exist on the destruction of vegetation are also not enforced (Hunter, 1991). Despite repeated calls for the designation and maintenance of forest reserves, no appreciable progress has been made to date. Proposed forest protection must include Moheli, where the degree of habitat loss is less severe, large tracts of unspoilt forest still exist and the human population pressure is less acute. Moheli should be assessed for its suitability as a site for any initial restocking of P. livingstonii.

The mongoose lemur, one of the most endangered lemurs in Madagascar (Harcourt and Thornback, 1990), and the Anjouan scops owl Otus capnodes, rediscovered in 1992 (R. Safford, pers. comm.), would also benefit from protection in forest reserves.

Environmental education is an essential part of conservation management in the Comores. This should stress the interdepen- 
dence of the forest and its fauna; protecting the forest is as much for the benefit of Comoriens (for whom it is a vital resource) as for the forest fauna. Environmental videos on the importance of forests and the role of fruit bats in forest regeneration are currently in preparation by Action Comores. These will ensure that Comoriens will be able to differentiate between the two Pteropus species; at present few Comoriens appreciate this distinction.

A captive-breeding programme at Jersey Zoo started in 1992 now has 10 males and two females. One female has already bred successfully in captivity and the second female, pregnant on capture, has also given birth (J. B. Carroll, pers. comm.). However, more females are urgently required, necessitating a further capture operation. The success of the Rodrigues fruit bat $P$. rodricensis in captivity (Carroll and Mace, 1988) is encouraging for the prospect of $P$. livingstonii. The captivebreeding programme should provide individuals for eventual reintroduction, as well as being a source of research material and a focus for fund-raising.

The IUCN Action Plan for fruit bats places $P$. livingstonii as 'endangered', priority grade 1 ; included in this category are taxa whose numbers have been reduced to a critical level and/or whose habitat has been so drastically reduced that they are considered to be in danger of immediate extinction (Mickleburgh et al., 1992). $P$. livingstonii clearly merits its placing in this category. The small population is limited to a few major roost sites and relies on montane forest, a threatened and rapidly disappearing habitat. It may be that the population is stable at this low level: there is evidence of breeding over several years and at several roosts (Trewhella et al., 1993). However, the low numbers make the population very vulnerable and a continued effort towards the conservation of this species and its forest habitat is essential.

\section{Acknowledgments}

Action Comores is grateful to The Leverhulme Trust, The People's Trust for Endangered Species,
The Fauna and Flora Preservation Society, British Airways Assisting Nature Conservation scheme and the Royal Geographical Society for grants to support this field work. Action Comores is also grateful to JWPT, Bristol Ecological Consultants Limited and Professor P. Racey for their help and advice. Action Comores is grateful to the following people and organizations in the Comores: the Comorien Government; Centre National de Documentation et Recherche Scientifique; the Directeur Régional de l'Environnement (Anjouan), Mohamed Moutui; Care-Comores; Peace Corps; Kathryn Hunter and Wildman; Miriam van Reennen and Barbara Collins; Mohamed Attoumane; Ahmed Yatima; Roger Safford; and to Janette Young and Rob Saw and the many others who helped the expedition. The authors are particularly grateful to the other expedition members, Richard Bullock, Jonathan Davies and Stephanie Wray.

\section{References}

Action Comores. 1992. The Final Report of the University of Bristol Comoros 1992 Expedition. W.J. Trewhella and P.F. Reason. Unpubl. report, University of Bristol.

Action Comores. 1993. The Final Report of the Action Comores 1993 Expedition to the Comoro Islands. Unpubl. report, University of Bristol.

Battistini, P. and Vérin, R. 1984. Geographie des Comores. Agence de Coopération Culturelle et Technique, Paris.

CARE-Comores 1991. Summary of Inventory Findings. Unpubl, report for CARE-Comores.

Carroll, J.B. 1985. The flying foxes (Pteropus spp.) of the western Indian Ocean islands (and a footnote on Rousettus obliviosus). Bat News, No. 4, 4-5.

Carrol, J.B. and Mace, G.M. 1988. Population management of the Rodrigues fruit bat Pteropus rodricensis in captivity. Int. Zoo Yearbook, 27, 70-78.

Carroll, J.B. and Thorpe, I.C. 1991. The conservation of Livingstone's fruit bat Pteropus livingstonii, Gray 1866: a report on an expedition to the Comores in 1990. Dodo, J. Jersey Wildl. Preserv. Trust, 27, 26-40.

Cheke, A.S. and Dahl, J.F. 1981. The status of bats on western Indian Ocean islands, with special reference to Pteropus. Mammalia, 1, 205-238.

Cox, P.A., Elmqvist, T., Pierson, E.D. and Rainey, W.E. 1992. Flying foxes as pollinators and seed dispersers in Pacific island ecosystems. In Pacific Island Flying Foxes: Proceedings of an International Conservation Conference (eds D. E. Wilson and G. L. Graham), pp. 18-23. US Fish and Wildlife Service Biological Report 90. US Department of the Interior, Fish and Wildlife Service, Washington, DC. 
Harcourt, C and Thornback, J. 1990. Lemurs of Madagascar and the Comoros. The IUCN Red Data Book. IUCN, Gland and Cambridge.

Hartley, F.G. and Leaper, R. 1991. Livingstone's Giant Flying Fox: An Initial Report on the 1991 Study. Unpubl. report, University of Bristol.

Hunter, K. 1991. Forest Management Plan. Unpubl. report for CARE-Comores.

Mickleburgh, S.P., Hutson, A.M. and Racey, P. 1992. Old World Fruit Bats: An Action Plan for their Conservation. IUCN, Gland, Switzerland.

Milne-Edwards, A. and Oustalet, E. 1888. Etudes sur les mammifères et les oiseaux des îles Comores. Nouv. Archs. Mus. Hist. nat. Paris, 10, 219-297.

Nicoll, M.E. and Racey, P.A. 1981. The Seychelles fruit bat, Pteropus seychellensis seychellensis. Afr. J. Ecol. 19, 361-364.

Pierson, E.D. and Rainey, W.E. 1992. The biology of flying foxes of the genus Pteropus: a review. In Pacific Island Flying Foxes: Proceedings of an International Conservation Conference (eds D. E. Wilson and G. L. Graham), pp. 1-17. US Fish and Wildlife Service Biological Report 90. US Department of the Interior, Fish and Wildlife Service, Washington, DC.

Racey, P.A. 1979. Two bats in the Seychelles. Oryx, 15, 148-152.
Tattersall, I.M. 1977. Lemurs of the Comoro Islands. Oryx, 12, 584-590.

Thorpe, I. 1989. University of East Anglia Comoro Islands Expedition 1989. Unpubl. report, University of East Anglia.

Trewhella, W.J., Reason, P.F., Davies, J.G. and Wray, $S$. (in press). Observations on the timing of reproduction in the congeneric Comoro Island fruit bats, Pteropus livingstonii (Gray 1866) and P. s. comorensis (Nicoll 1908). J. Zool. Lond.

University of East Anglia. 1988. University of East Anglia Comoro Islands Expedition 1988, final report. Unpubl. report, University of East Anglia.

Weightman, B. 1987. The Crisis on Anjouan. Unpubl. report to FAO, Rome.

Young, J.A., Saw, R. and Trewhella, W.J. (in press). Establishing a captive breeding programme for the endangered Livingstone's fruit bat (Pteropus livingstonii Gray 1866): the 1993 capture expedition. Dodo, J. Jersey Wildl. Preserv. Trust, 29.

P. F. Reason and W. J. Trewhella, Action Comores, School of Biological Sciences, University of Bristol, Woodland Road, Bristol BS8 1UG, UK. 